Egyptian Journal of Aquatic Biology \& Fisheries

Zoology Department, Faculty of Science,

Ain Shams University, Cairo, Egypt.

ISSN $1110-6131$

Vol. 25(2): $659-675$ (2021)

www.ejabf.journals.ekb.eg

\title{
The Effect of a Mixture of Environmental Pollutants on Some Biomarkers in the Nile tilapia (Oreochromis niloticus)
}

\author{
Eman A. A. Abdel-Hamid ${ }^{1 *}$, Sherien H. Hashem ${ }^{2}$ and Amany A. Ghareib ${ }^{3}$
}

1. Limnology Department

2. Fish Ecology and Biology Department

3. Hatchery and Fish Physiology Department

Agriculture Research Centre (ARC), Central Laboratory for Aquaculture Research (CLAR), Abbassa, Abo-Hammad, Sharqia, Egypt

*Corresponding author: $\underline{\text { e_abdelhamid2014@yahoo.com. }}$

\section{ARTICLE INFO \\ Article History: \\ Received: March 18, 2021 \\ Accepted: April 13, 2021 \\ Online: April 26, 2021}

Keywords:

Nile tilapia,

Copper sulfate,

Jasper Herbicide,

Biomarkers,

Antioxidants.
ABSTRACT

Copper sulfate and jasper herbicide are heavily used in the aquatic environment to kill algae, bacteria, Mollusca, and unwanted plants. Therefore, this study was carried out to evaluate the effect of the chronic toxicity of those compounds, separately and mixed, on some biomarkers in the Nile tilapia, Oreochromis niloticus. Results showed that a $33.50 \mathrm{mg} / 1$ found of the 96h-LC $\mathrm{L}_{50}$ of copper sulfate decreased in the mixture to record $11.70 \mathrm{mg} / \mathrm{l}$. While in the case of a $3.80 \mathrm{mg} / 1$ found of jasper, it marked a decreasing record of $2.20 \mathrm{mg} / \mathrm{l}$ in the mixture. Afterward, fish were exposed to the sublethal concentrations (1/10 of the 96h-LC50) separately and in a mixture for 28 days to detect the changes in biomarkers. Whereas the rest of the fish were transferred to water free of those chemicals for 30 days to study the recovery. Superoxide dismutase (SOD), glutathione peroxidase (GPx), catalase (CAT), and malondialdehyde (MDA) decreased in all treatments. The SOD and MDA didn't recover in fish exposed to the mixture. The GPX and CAT exceeded the control during the recovery. Alanine transaminase (ALT) and alkaline phosphatase (ALP) elevated in all treatments on the $4^{\text {th }}$ day, and declined on the $28^{\text {th }}$ of exposure, and didn't recover. Acetyl-cholinesterase (AChE) decreased in all treated groups and still impacted in fish exposed previously to the mixture during recovery. Uric acid increased in all treated groups and recovered in fish exposed alone to jasper. Creatinine increased in all groups and recovered in those treated with copper sulfate and jasper separately. Albumin decreased in all treated groups during all periods and didn't recover. In general, the mixture of copper sulfate and jasper herbicide is more toxic for $O$. niloticus and the recovery state is difficult to occur for fish previously treated with the mixture.

\section{INTRODUCTION}

Tilapia species are worldly considered the second most important and widely grown group of farmed fish after carps. Egypt is the $2^{\text {nd }}$ largest producer of the farmed Nile tilapia after China, presenting more than $80 \%$ of total tilapia production (El-Sayed, 2013). The 
Nile tilapia is an omnivorous fish that feeds on detritus, phytoplankton and zooplankton. Consequently, if it was reared in polluted water, it can accumulatein its tissues high concentrations of heavy metals and metabolites of organic pesticides, causing a health hazard for both fish and human.

The heavy use of pesticides and other chemicals in the environment can expose fish, including tilapia, to a diverse set of complex mixtures of these substances. The mixture of toxicity can be predicted by the summation of their individual component toxicities, but sometimes in some mixtures interactions can occur, altering the toxicity to a more or less than expected compared to their components (Kelly et al., 2016).

Copper sulfate is an inorganic compound used as bactericide, fungicide, molluscicide and algaecide. Its harmful effect on fish depends on fish species and water. The more hardness and alkalinity water is, the less the danger of copper sulfate to fish. Thus, if there is a need to apply copper sulfate, then a test of the water should come first. Copper sulfate causes rapid die-off of algae and other plants, leading to an increase of the organic matter, ammonia and oxygen depletion in water which results in fish mortality. Most algaecides and many aquatic herbicides contain copper-based compounds (Wagner $\boldsymbol{e t}$ al., 2017). It is noted that, copper at low concentrations, is a minor nutrient for plants and animals, but at higher concentrations, ionic copper herbicides are considered toxic to fish and other non-targeted organisms (Mastin \& Rodgers, 2000).

In addition, jasper $520 \mathrm{EC}$ herbicide is an organic compound with an active constituent of $520 \mathrm{~g} / \mathrm{l}$ haloxyfop-R-methyl ester. It controls grasses in many crops. It is not allowed to be used in aquatic environments except in specific discrete areas, where there is a biosecurity emergency and where no alternative herbicide is available for specific water weed eradication (EPA, 2012).

The mixtures of environmental pollutants in aquatic ecosystems may exert severe damage for the aquatic organisms due to their capability to induce oxidative stress in those aquatic organisms, including fish (Lopez-Lopez et al., 2011).

Remarkably, heavy metals and pesticides can induce oxidative stress by generating free radicals (Desai \& Bhilave, 2018). The evaluation of biochemical systems involved in detoxification of reactive oxygen can be useful as biomarkers of aquatic contamination in resident indicator species (Frenzilli et al., 2004). Borkovic' et al. (2005) recorded that antioxidants have been proposed as biomarkers of contaminants inducing oxidative stress in fish as their induction reflects a response to pollutants. Reactive oxygen species (ROS), may adversely affect organisms. However, increased ROS levels can cause a significant damage to cell structures (Ahmed et al., 2004).

ROS and other free radicals are continually detoxified and removed in cells by an antioxidant defense system comprising both antioxidant enzymes, including superoxide dismutase (SOD), catalase (CAT), and glutathione peroxidase (GPX). The antioxidant enzyme; superoxide dismutase (SOD), plays a key role in the defense of all aerobic organisms against toxic oxygen species, which are generated under oxygen stress (Stajner 
et al., 2003). Furthermore, Desai and Bhilave (2018) stated that superoxide dismutase (SOD) and catalase (CAT) play important roles in protecting the cell against the potentially toxic effects of environmental pollutants. Moreover, lipid peroxidation is a well-established mechanism of cellular injury in animals, and is used as an indicator of oxidative stress in cells. Additionally, malondialdehyde is widely used as an indicator of lipid peroxidation (Esterbauer et al., 1991). In fact, increased levels of lipid peroxidation products have been associated with a variety of chronic diseases in both humans and other vertebrates (AllenGil \& Martynov, 1995).

Many pollutants inhibit acetyl-cholinesterase (AChE) activity, causing an accumulation on the nerve synapses that leads to subsequent disruption of neural transmission in both central and peripheral nervous systems (Anam \& Maitra, 1995). Choudhury (2018) listed several studies about the devastating effects of pesticides in various biochemical parameters like ALT, ALP, uric acid, creatinine and albumin, which led to disturbances in various fish organs especially the liver and the kidney.

In this essence, this study aimed to evaluate the effect of copper sulfate and jasper herbicide, which are widely used separately and mixed in Egypt environment on some biomarkers of Nile tilapia "O. niloticus" cultured there.

\section{MATERIALS AND METHODS}

\subsection{Fish}

Apparently healthy Nile tilapia "Oreochromis niloticus" with average weight $20.5 \pm 1.5 \mathrm{~g}$ were collected from the fish farm of Central Laboratory for Aquaculture Research (CLAR), Abbassa, Abo-Hammad, Sharqia, Egypt. The collected fish were transported immediately into the indoor tanks in the wet lab of the Biology and Ecology Department and acclimated to the laboratory conditions for 2 weeks.

\subsection{Pollutants}

i. Inorganic Compound: Copper sulfate $\left(\mathrm{CuSO}_{4} \cdot 5 \mathrm{H}_{2} \mathrm{O}\right)$ : It was purchased from Sigma (Egyptian International Center for Import, Cairo, Egypt).

ii. Organic Compound: Commercial, Jasper 520 Herbicide. Active constituent is $520 \mathrm{~g} / \mathrm{l}$ haloxyfop-R-methyl ester. It was purchased from the pesticide market in Zagazig city, Sharqia, Egypt.

\subsection{Experimental design}

\subsubsection{Determination of the $96 \mathrm{~h}-\mathrm{LC}_{50}$}

Eight groups of fish, each in 3 replicates were distributed among 60L capacity glass aquaria filled with dechlorinated and aerated tap water, with 8 fish/aquarium and were exposed to 8 different concentrations of copper sulfate alone. A similar method was done with the commercial form of jasper herbicide alone. After that, the same sequence was repeated with different mixtures of copper sulfate and jasper herbicide. All laboratory conditions were maintained constant. Fish deaths and abnormal behavior were recorded 
daily for 4 days. Then, the values of the 96-h $\mathrm{LC}_{50}$ were calculated for each treatment according to Behreus and Karbeur (1953). The $96 \mathrm{~h}-\mathrm{LC}_{50}$ of copper sulfate was found 33.5 $\mathrm{mg} / \mathrm{l}$ and decreased in the mixture to $11.70 \mathrm{mg} / \mathrm{l}$. Whereas the $96 \mathrm{~h}-\mathrm{LC}_{50}$ of jasper alone was found $3.8 \mathrm{mg} / \mathrm{l}$ and decreased to $2.2 \mathrm{mg} / \mathrm{l}$ in the mixture.

\subsubsection{Experimental procedures}

The other Nile tilapia "O.niloticus" were divided into 4 treatment groups, each in 3replicates, each replicate with 10 fish in 100-L capacity glass aquarium. The $1^{\text {st }}$ group (T1) was kept as control (0.0). The $2^{\text {nd }}$ group (T2) was exposed to $1 / 1096 \mathrm{~h}-\mathrm{LC}_{50}(3.35 \mathrm{mg} / \mathrm{l})$ of copper sulfate. The $3^{\text {rd }}$ group (T3) was exposed to $1 / 1096 \mathrm{~h}-\mathrm{LC}_{50}(0.38 \mathrm{mg} / \mathrm{l})$ of jasper herbicide. The $4^{\text {th }}$ group (T4) was exposed to $1 / 10$ of the $96 \mathrm{~h}-\mathrm{LC}_{50}$ of copper sulfate and jasper herbicide in a mixture $(1.17 \& 0.22 \mathrm{mg} / \mathrm{l}$, respectively).

\begin{tabular}{lcc}
\multicolumn{2}{c}{ The experimental treatment groups } \\
\hline Treatment groups & $\begin{array}{c}\text { Copper sulfate } \\
(\mathrm{mg} / \mathrm{l})\end{array}$ & $\begin{array}{c}\text { Jasper herbicide } \\
(\mathrm{mg} / \mathrm{l})\end{array}$ \\
\hline T1 (Control) & 0.0 & 0.0 \\
T2 (Copper sulfate) & 3.35 & 0.0 \\
T3 (Jasper herbicide) & 0.0 & 0.38 \\
T4 (Mixture) & 1.17 & 0.22
\end{tabular}

All aquaria were supplied with compressed air via air-stones from air pumps. Wellaerated water was provided from a storage fiberglass tank. The ambient temperature ranged from 26 to $29^{\circ} \mathrm{C}$. Dead fish once observed at any aquarium were removed. Fish were offered $35 \%$ protein diet at a rate of $2 \%$ of live body weight daily, divided into 2 equal meals; 5 days a week for 4 weeks. A three quarter of the aquarium's water was siphoned daily along with fish excreta, and replaced with an equal volume of water, maintaining the same pollutant concentration per each treatment group.

\subsubsection{Analysis of water physico-chemical parameters}

Water analyses were monitored weekly during the experimental period. Dissolved oxygen and temperature were measured on site with a YSI model 58 oxygen meter (Yellow Spring Instrument Co., Yellow Springs, Ohio, USA). The pH was measured using a pHmeter (Digital Mini-pH Meter, model 55, Fisher Scientific, USA). The unionized ammonia was measured using DREL/2 HACH kits (HACH Co., Loveland, Co., USA). Total alkalinity and total hardness were measured by titration as described by Boyd (1984). In all groups, dissolved oxygen concentrations ranged from 5.8 to $6.8 \mathrm{mg} \mathrm{L}^{-1}$. The range of the ambient water temperature was $27-29^{\circ} \mathrm{C}$. The $\mathrm{pH}$ range was $7.6-8.5$, and the unionized ammonia concentration was $\left(<0.30 \mathrm{mg} \mathrm{L}^{-1}\right)$ less than the critical level (Boyd, 1990). Total hardness and total alkalinity were $160-200 \mathrm{mg} \mathrm{L}^{-1}$ and $140-170 \mathrm{mg} \mathrm{L}^{-1}$ as $\mathrm{CaCO}_{3}$, respectively. 


\subsubsection{Biochemical analyses}

Fish were anaesthetized by MS-222, and blood samples were collected from the caudal veins on the $4^{\text {th }}$ and $28^{\text {th }}$ day of exposure. Then, they were centrifuged to obtain the plasma, which was kept in deep freezer till analyses.

Superoxide dismutase (SOD) activity was determined by the method of Flohé and Otting (1984). Glutathione peroxidase (GPX) activity was determined by the method of Flohé and Gunzler (1984). Catalase (CAT) activity was determined according to the technique described by Beutler (1975). Malondialdehyde (MDA) was determined according to Ohkawa et al. (1979).

Alanine transferase (ALT) was determined according to Reitman and Frankel (1957). Alkaline phosphatase (ALP) was determined according to the method of Bergmeyer (1974). Acetyl-cholinesterase (AChE) activity was measured as described by Ellman et al. (1961). Uric acid was determined according to Barham and Trinder (1972). Creatinine was determined according to Henry (1964). Determination of plasma albumin was done according to the method described by Doumas et al. (1971).

\subsection{Recovery experiment}

At the end of the exposure period (28 days), the rest 10 fish of each treated group were transferred to dechlorinated and oxygenated water; completely free of copper sulfate and jasper herbicide for 30 days. the same analyses were achieved at the end of this period.

\subsection{Statistical analysis}

Statistical analyses were carried out using statistical SPSS package version 19 for windows. A one-way analysis of variance (ANOVA) followed by a Duncan's post Hoc test were performed to identify any significant differences between the treatments $(p \leq 0.05)$. All results were given in a mean \pm standard error of the mean.

\section{RESULTS}

In the present study, the $96 \mathrm{~h}-\mathrm{LC}_{50}$ of copper sulfate for the Nile tilapia "O. niloticus" was found $33.5 \mathrm{mg} / \mathrm{l}$ when applied alone, while in the mixture with jasper, this value decreased to $11.7 \mathrm{mg} / \mathrm{l}$. Moreover, the $96 \mathrm{~h}-\mathrm{LC}_{50}$ of jasper was found $3.80 \mathrm{mg} / \mathrm{l}$ when applied alone, and decreased to $2.20 \mathrm{mg} / \mathrm{l}$ when applied in a mixture with copper sulfate (Fig. 1). Afterwards, this study was concerned to determin the impact of sublethal $(1 / 10$ 96h-LC $\mathrm{C}_{50}$ ) concentration of copper sulfate and jasper in separate and in mixture on plasma biomarkers of the Nile tilapia "O. niloticus" after 4 and 28 days of exposure, and define the recovery status after transferring fish to water free of these toxicants for 30 days. 


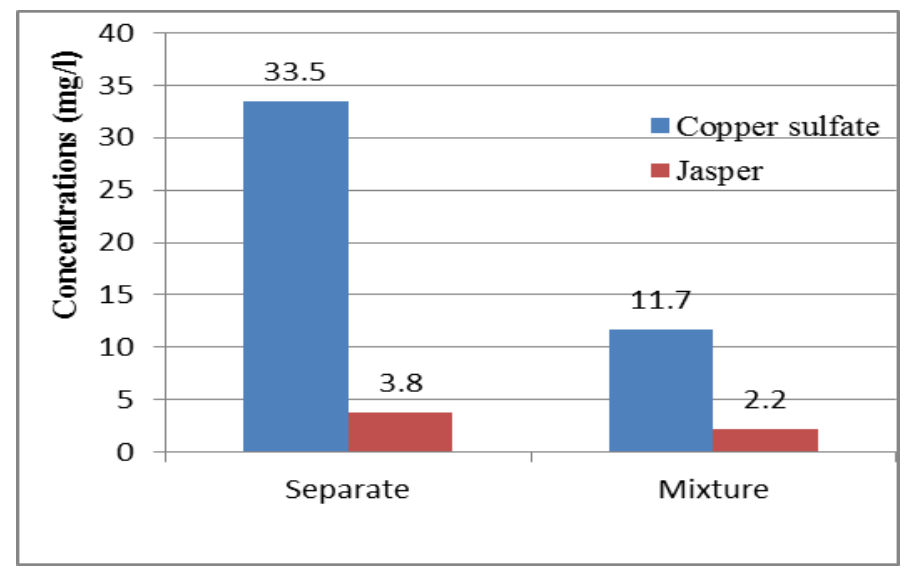

Fig. 1: The 96h-LC $\mathrm{LC}_{50}(\mathrm{mg} / \mathrm{l})$ of copper sulfate and jasper for the Nile tilapia "O. niloticus" separately and in a mixture.

In Table (1), the SOD activity decreased recording the lowest value in the fish exposed to the mixture $(2.50 \pm 0.05 \& 2.14 \pm 0.01 \mathrm{u} / \mathrm{ml})$ for 4 and 28 days, respectively $(\mathrm{P} \leq 0.05)$. The recovery was noticed in fish groups treated previously with copper sulfate or jasper in separate, but in that treated with the mixture, fish were still impacted (Fig. 2, a). In addition, the GPX recorded the same trend; reaching the lowest value in fish treated with the mixture $\left(65.00 \pm 1.15 \& 66.00 \pm 0.58 \mathrm{u} / 1\right.$, on the $4^{\text {th }}$ and $28^{\text {th }}$ day of exposure, respectively) in comparison with the control group $(\mathrm{P} \leq 0.05)$. It increased

Table 1: Effect of chronic exposure of the Nile tilapia "O. niloticus" to copper sulfate and jasper Herbicide, separately and mixed, on plasma SOD, GPX, CAT and MDA.

\begin{tabular}{|c|c|c|c|c|c|}
\hline Periods & Treatments & $\begin{array}{l}\text { SOD } \\
(\mathrm{u} / \mathrm{ml})\end{array}$ & $\begin{array}{l}\text { GPX } \\
(\mathrm{u} / \mathrm{l})\end{array}$ & $\begin{array}{l}\text { CAT } \\
(\mathrm{u} / \mathrm{l})\end{array}$ & $\begin{array}{c}\text { MDA } \\
(\mathrm{nmol} / \mathrm{ml})\end{array}$ \\
\hline \multirow{4}{*}{$4^{\text {th }}$ Day } & $\mathrm{T} 1$ & $3.87 \pm 0.07^{\mathrm{A}}$ & $93.00 \pm 1.15^{\mathrm{D}}$ & $158.00 \pm 0.58^{\mathrm{D}}$ & $16.99 \pm 0.08^{\mathrm{A}}$ \\
\hline & $\mathrm{T} 2$ & $2.55 \pm 0.011^{\mathrm{BC}}$ & $65.33 \pm 1.45^{\mathrm{F}}$ & $129.00 \pm 2.31^{\mathrm{F}}$ & $13.30 \pm 0.41^{\mathrm{C}}$ \\
\hline & $\mathrm{T} 3$ & $2.85 \pm 0.02^{\mathrm{B}}$ & $65.67 \pm 0.67^{\mathrm{F}}$ & $100.33 \pm 4.91^{\mathrm{H}}$ & $13.17 \pm 0.19^{C}$ \\
\hline & $\mathrm{T} 4$ & $2.50 \pm 0.03^{\mathrm{C}}$ & $65.00 \pm 1.15^{\mathrm{F}}$ & $91.33 \pm 0.88^{\mathrm{K}}$ & $11.87 \pm 0.13^{\mathrm{D}}$ \\
\hline \multirow{4}{*}{$28^{\text {th }}$ Days } & $\mathrm{T} 1$ & $3.87 \pm 0.06^{\mathrm{A}}$ & $91.00 \pm 1.00^{\mathrm{D}}$ & $156.00 \pm 1.53^{\mathrm{D}}$ & $16.95 \pm 0.10^{\mathrm{A}}$ \\
\hline & $\mathrm{T} 2$ & $2.74 \pm 0.36^{\mathrm{BC}}$ & $76.67 \pm 2.19^{\mathrm{E}}$ & $137.00 \pm 0.58^{\mathrm{E}}$ & $11.67 \pm 0.19^{\mathrm{D}}$ \\
\hline & $\mathrm{T} 3$ & $2.39 \pm 0.03^{\mathrm{CD}}$ & $74.00 \pm 1.15^{\mathrm{E}}$ & $120.00 \pm 0.58^{G}$ & $11.13 \pm 0.01^{\mathrm{E}}$ \\
\hline & $\mathrm{T} 4$ & $2.14 \pm 0.01^{\mathrm{D}}$ & $66.00 \pm 0.58^{\mathrm{F}}$ & $105.67 \pm 0.88^{\mathrm{H}}$ & $10.87 \pm 0.03^{\mathrm{E}}$ \\
\hline \multirow{4}{*}{ Recovery } & $\mathrm{T} 1$ & $3.92 \pm 0.03^{\mathrm{A}}$ & $90.67 \pm 1.86^{\mathrm{D}}$ & $155.67 \pm 1.86^{\mathrm{D}}$ & $17.01 \pm 0.07^{\mathrm{A}}$ \\
\hline & $\mathrm{T} 2$ & $3.75 \pm 0.02^{\mathrm{A}}$ & $108.00 \pm 4.16^{\mathrm{C}}$ & $174.33 \pm 1.20^{\mathrm{C}}$ & $17.14 \pm 0.10^{\mathrm{A}}$ \\
\hline & $\mathrm{T} 3$ & $3.75 \pm 0.04^{\mathrm{A}}$ & $116.00 \pm 2.08^{\mathrm{B}}$ & $195.67 \pm 2.16^{\mathrm{B}}$ & $16.35 \pm 0.18^{\mathrm{B}}$ \\
\hline & $\mathrm{T} 4$ & $2.51 \pm 0.02^{\mathrm{BC}}$ & $148.67 \pm 3.18^{\mathrm{A}}$ & $232.67 \pm 3.53^{\mathrm{A}}$ & $13.17 \pm 0.15^{\mathrm{C}}$ \\
\hline
\end{tabular}

Means \pm SE with the same letters in the same column are not significantly different $(\mathrm{P} \leq 0.05)$. 

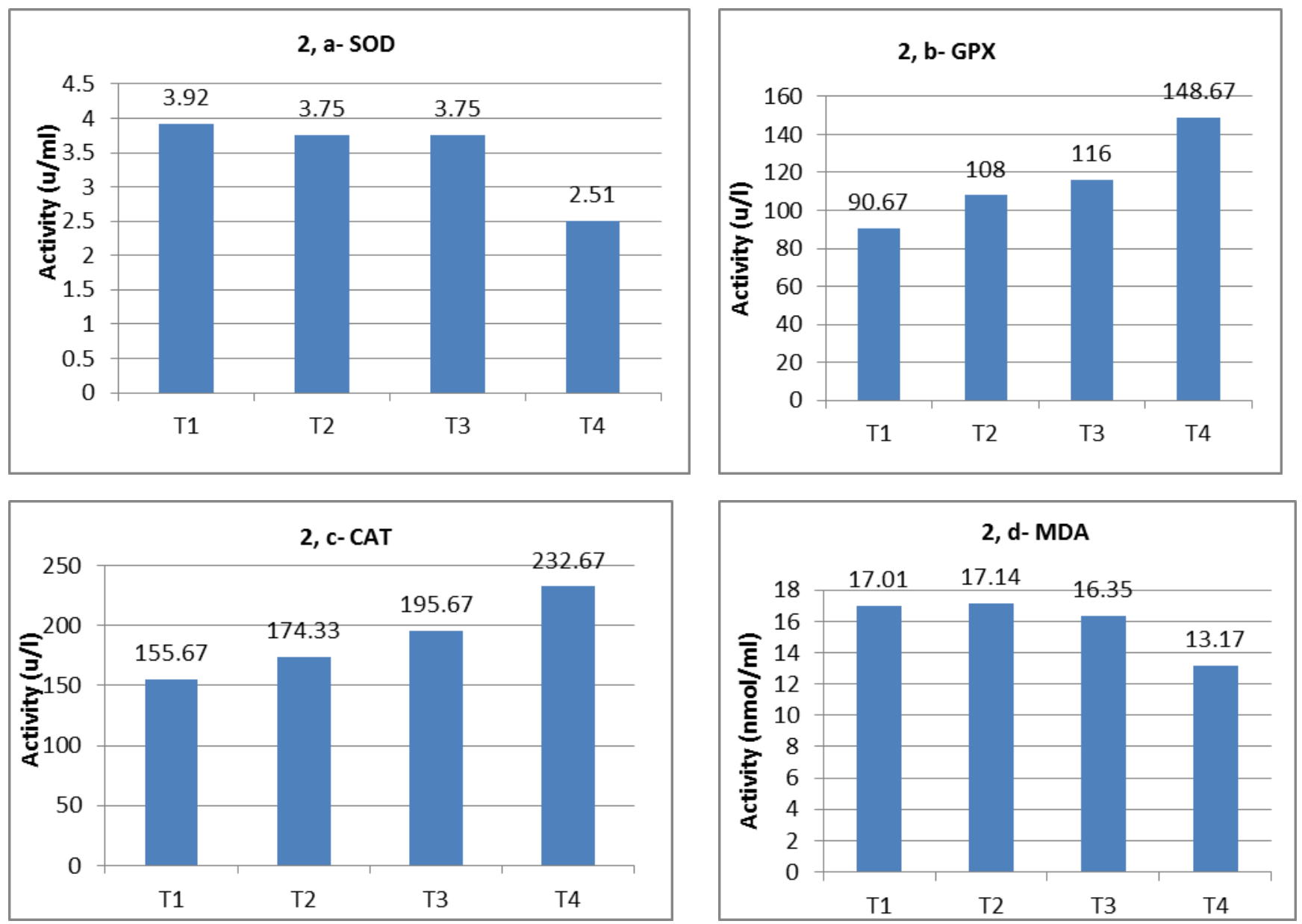

Fig. 2: Recovery of plasma SOD, GPX, CAT and MDA of the Nile tilapia “O. niloticus" previously exposed to copper sulfate and jasper herbicide separately and in a mixture.

significantly during the recovery in all fish groups and the effect of the mixture was the highest (Fig. 2, b). The same results were observed in the case of CAT, which decreased to the lowest values on the $4^{\text {th }}$ and $28^{\text {th }}$ day of exposure $(91.33 \pm 0.88 \& 105.67 \pm 0.088 \mathrm{u} / \mathrm{l}$, respectively) in comparison with the control, $(\mathrm{P} \leq 0.05)$. In the recovery, the values of CAT exceeded those in the control $(232.67 \pm 3.53 \mathrm{u} / \mathrm{l})$; in fish treated previously with the mixture (Fig. 2, c). The MDA levels decreased significantly in all treated fish groups, reaching a highly significant reduction in fish group exposed to the mixture of copper sulfate and jasper herbicide for 4 and 28 days, and recorded $11.67 \pm 0.19$ and $10.87 \pm 0.03 \mathrm{nmol} / \mathrm{ml}$, respectively, $(\mathrm{P} \leq 0.05)$. The recovery occurred in fish groups exposed to copper sulfate and jasper herbicide in separate, while in those previously exposed to the mixture recovery was still impacted (Fig. 2, d).

Data in Table (2), showed a significant increase in plasma ALT and ALP activities in all treated groups on the $4^{\text {th }}$ day of exposure, while the highest effect was detected in the fish group exposed to the mixture $(40.93 \pm 0.42 \& 139.67 \pm 1.20 \mathrm{u} / \mathrm{l}$, respectively). After that, ALT and ALP decreased significantly on the $28^{\text {th }}$ day recording $13.50 \pm 0.50$ and $42.00 \pm 0.58 \mathrm{u} / \mathrm{l}$, 
respectively in the fish group exposed to the mixture $(\mathrm{P} \leq 0.05)$. The recovery status didn't occur completely in all groups, and the highest effect was recorded in the fish exposed to the mixture (Fig. 3, a).

Table 2: Effect of chronic exposure of the Nile tilapia "O. niloticus" to copper sulfate and jasper Herbicide, separately and in a mixture, on plasma ALT, ALP and AChE.

\begin{tabular}{|c|c|c|c|c|}
\hline Periods & Treatments & $\begin{array}{l}\text { ALT } \\
(\mathrm{u} / \mathrm{l})\end{array}$ & $\begin{array}{l}\text { ALP } \\
(\mathrm{u} / \mathrm{l})\end{array}$ & $\begin{array}{c}\mathrm{AChE} \\
(\mathrm{uM})\end{array}$ \\
\hline \multirow{4}{*}{$4^{\text {th }}$ Day } & $\mathrm{T} 1$ & $22.03 \pm 0.12^{\mathrm{D}}$ & $72.67 \pm 0.33^{\mathrm{D}}$ & $11.07 \pm 0.09^{\mathrm{A}}$ \\
\hline & $\mathrm{T} 2$ & $32.70 \pm 0.21^{\mathrm{B}}$ & $96.67 \pm 10.20^{\mathrm{B}}$ & $8.67 \pm 0.12^{\mathrm{D}}$ \\
\hline & $\mathrm{T} 3$ & $27.37 \pm 0.22^{\mathrm{C}}$ & $77.67 \pm 1.20^{\mathrm{C}}$ & $8.57 \pm 0.18^{\mathrm{D}}$ \\
\hline & $\mathrm{T} 4$ & $40.93 \pm 0.42^{\mathrm{A}}$ & $139.67 \pm 1.20^{\mathrm{A}}$ & $6.93 \pm 0.09^{\mathrm{G}}$ \\
\hline \multirow{4}{*}{$28^{\text {th }}$ Days } & $\mathrm{T} 1$ & $21.83 \pm 0.15^{\mathrm{D}}$ & $74.00 \pm 0.58^{\mathrm{D}}$ & $10.96 \pm 0.08^{\mathrm{AB}}$ \\
\hline & $\mathrm{T} 2$ & $18.93 \pm 0.145^{\mathrm{F}}$ & $39.330 .88^{\mathrm{H}}$ & $7.60 \pm 0.12^{\mathrm{E}}$ \\
\hline & $\mathrm{T} 3$ & $16.77 \pm 0.28^{\mathrm{G}}$ & $39.001 .15^{\mathrm{K}}$ & $7.27 \pm 0.03^{\mathrm{F}}$ \\
\hline & $\mathrm{T} 4$ & $13.50 \pm 0.50^{\mathrm{H}}$ & $42.00 \pm 0.58^{\mathrm{GH}}$ & $6.20 \pm 0.06^{\mathrm{H}}$ \\
\hline \multirow{4}{*}{ Recovery } & $\mathrm{T} 1$ & $21.83 \pm 0.19^{\mathrm{D}}$ & $73.33 \pm 0.33^{\mathrm{D}}$ & $10.89 \pm 0.02^{\mathrm{AB}}$ \\
\hline & $\mathrm{T} 2$ & $20.13 \pm 0.58^{\mathrm{E}}$ & $55.67 \pm 0.88^{F}$ & $10.83 \pm 0.07^{\mathrm{AB}}$ \\
\hline & $\mathrm{T} 3$ & $19.77 \pm 0.24^{\mathrm{EF}}$ & $63.00 \pm 1.15^{\mathrm{E}}$ & $10.73 \pm 0.12^{\mathrm{B}}$ \\
\hline & $\mathrm{T} 4$ & $13.73 \pm 0.30^{\mathrm{H}}$ & $44.33 \pm 0.88^{\mathrm{G}}$ & $8.97 \pm 0.12^{\mathrm{C}}$ \\
\hline
\end{tabular}

Means \pm S.E with the same letters in the same column are not significantly different $(\mathrm{p} \leq 0.05)$.

Moreover, acetyl-cholinesterase (AChE) was inhibited in all treated groups through the different periods of exposure $(\mathrm{P} \leq 0.05)$. It recovered in fish groups exposed previously to the copper sulfate and jasper herbicide in separate, but was still impacted in those exposed to the mixture (Fig. 3, b).
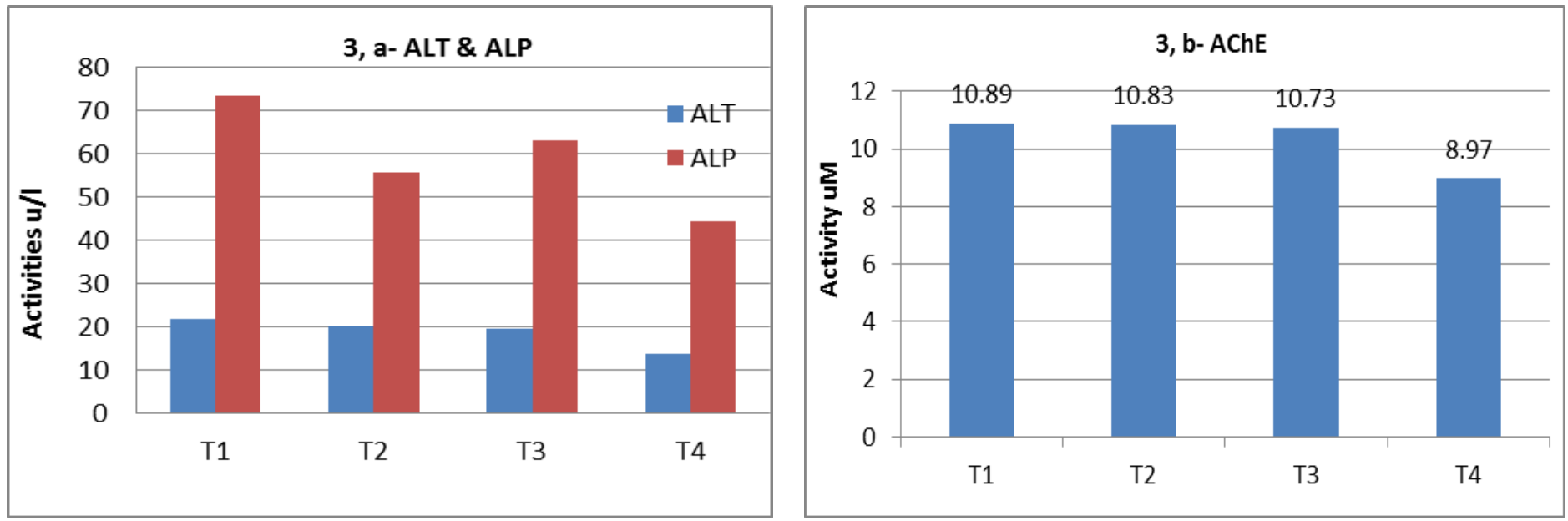

Fig. 3: Recovery of plasma ALT, ALP and AChE in the Nile tilapia "O. niloticus", previously exposed to copper sulfate and jasper herbicide separately and in a mixture. 
Plasma uric acid and creatinine levels increased significantly $(\mathrm{P} \leq 0.05)$ in all treated groups and through the different exposure periods (Table 3). Additionally, the recovery of the uric acid level was obtained in fish group treated with jasper herbicide alone $(2.75 \pm 0.01 \mathrm{mg} / \mathrm{dl})$. While, the creatinine was recovered in fish groups treated with copper sulfate and jasper in separate, and was still highly impacted in fish exposed previously to the mixture (1.27 $\pm 0.01 \mathrm{mg} / \mathrm{dl}$ ) (Fig. 4, a). Plasma albumin in fish exposed to copper sulfate and jasper herbicide in separate or in mixture, decreased significantly ( $\mathrm{P} \leq 0.05)$, and did not recover, recording the lowest values in fish treated with the mixture (Table 3 \& Fig. 4, b).

Table 3: Effect of chronic exposure of the Nile tilapia "O. niloticus" to copper sulfate and jasper Herbicide, separately and in a mixture, on plasma uric acid, creatine and albumin.

\begin{tabular}{|c|c|c|c|c|}
\hline Periods & Treatments & $\begin{array}{c}\text { Uric acid } \\
(\mathrm{mg} / \mathrm{dl})\end{array}$ & $\begin{array}{c}\text { Creatinine } \\
(\mathrm{mg} / \mathrm{dl})\end{array}$ & $\begin{array}{l}\text { Albumin } \\
\text { (g/dl) }\end{array}$ \\
\hline \multirow{4}{*}{$4^{\text {th }}$ Day } & $\mathrm{T} 1$ & $2.74 \pm 0.03^{\mathrm{C}}$ & $0.93 \pm 0.02^{\mathrm{D}}$ & $3.27 \pm 0.0^{\mathrm{A}}$ \\
\hline & $\mathrm{T} 2$ & $3.47 \pm 0.04^{\mathrm{A}}$ & $1.15 \pm 0.02^{\mathrm{C}}$ & $2.93 \pm 0.01^{\mathrm{B}}$ \\
\hline & $\mathrm{T} 3$ & $3.47 \pm 0.01^{\mathrm{A}}$ & $1.45 \pm 0.02^{\mathrm{A}}$ & $2.63 \pm 0.01^{\mathrm{C}}$ \\
\hline & $\mathrm{T} 4$ & $3.43 \pm 0.02^{\mathrm{AB}}$ & $1.25 \pm 0.02^{\mathrm{B}}$ & $2.21 \pm 0.01^{\mathrm{D}}$ \\
\hline \multirow{4}{*}{$28^{\text {th }}$ Days } & $\mathrm{T} 1$ & $2.68 \pm 0.02^{\mathrm{C}}$ & $0.93 \pm 0.01^{\mathrm{D}}$ & $3.33 \pm 0.01^{\mathrm{A}}$ \\
\hline & $\mathrm{T} 2$ & $3.53 \pm 0.07^{\mathrm{A}}$ & $1.25 \pm 0.02^{\mathrm{B}}$ & $2.10 \pm 0.07^{\mathrm{E}}$ \\
\hline & $\mathrm{T} 3$ & $3.13 \pm 0.03^{\mathrm{B}}$ & $1.27 \pm 0.01^{\mathrm{B}}$ & $2.28 \pm 0.02^{\mathrm{D}}$ \\
\hline & $\mathrm{T} 4$ & $3.23 \pm 0.07^{\mathrm{AB}}$ & $1.43 \pm 0.02^{\mathrm{A}}$ & $2.05 \pm 0.02^{\mathrm{E}}$ \\
\hline \multirow{4}{*}{ Recovery } & $\mathrm{T} 1$ & $2.69 \pm 0.03^{\mathrm{C}}$ & $0.93 \pm 0.02^{\mathrm{D}}$ & $3.32 \pm 0.01^{\mathrm{A}}$ \\
\hline & $\mathrm{T} 2$ & $3.21 \pm 0.33^{\mathrm{AB}}$ & $0.90 \pm 0.02^{\mathrm{DE}}$ & $3.01 \pm 0.06^{\mathrm{B}}$ \\
\hline & $\mathrm{T} 3$ & $2.75 \pm 0.01^{\mathrm{C}}$ & $0.87 \pm 0.01^{\mathrm{E}}$ & $2.95 \pm 0.02^{\mathrm{B}}$ \\
\hline & $\mathrm{T} 4$ & $3.53 \pm 0.01^{\mathrm{A}}$ & $1.27 \pm 0.01^{\mathrm{B}}$ & $1.64 \pm 0.07^{\mathrm{F}}$ \\
\hline
\end{tabular}

Means \pm SE with the same letters in the same column are not significantly different $(\mathrm{p} \leq 0.05)$.
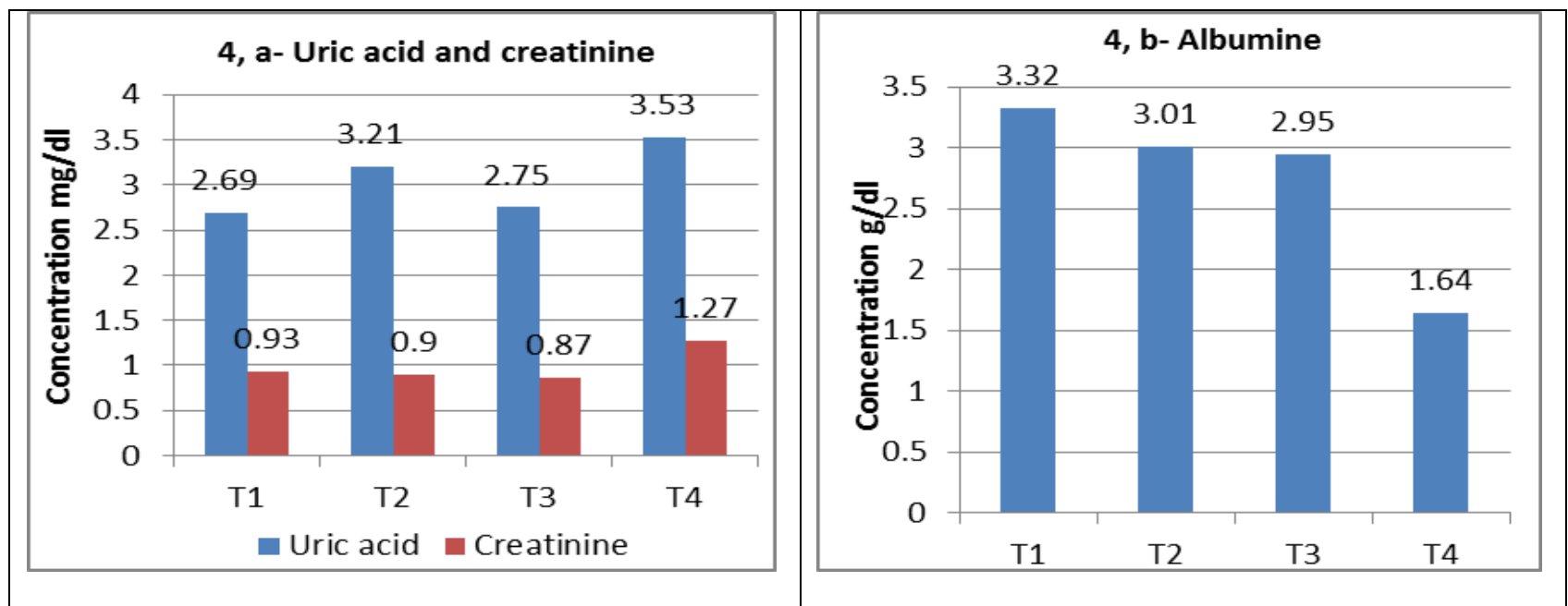

Fig. 4: Recovery of plasma, uric acid, creatinine and albumin of the Nile tilapia "O. niloticus", previously exposed to copper sulfate and jasper herbicide separately and in a mixture. 


\section{DISCUSSION}

Pollution forms a major threat to the life of all organisms and well-being of millions of people worldwide. The most important toxic compounds of aquatic habitats are pesticides and heavy metals (Khoshnood, 2017). Thus, the exposure of fish to these chemicals is responsible for the great loss of a good source of animal proteins, because fish play the major ecological role in the aquatic food chain; it acts as a key carrier of energy (Abed ElAziz et al., 1997).

Most studies have considered solely the toxicity of chemicals in isolation, whereas in the environment, organisms are exposed to a large number of different chemicals simultaneously. The assumption of a mixture of toxicity, based on the individual component data, can lead to a significant under/over estimation of the potential risk that a mixture may present (Kelly et al., 2016).

Experimentally, the $\mathrm{LC}_{50}$ is used to classify the toxicity of any chemical as nontoxic $\left(\mathrm{LC}_{50}>100 \mathrm{mg} / \mathrm{l}\right)$, highly toxic $(0.1>1 \mathrm{mg} / \mathrm{l})$, moderately toxic $(1>10 \mathrm{mg} / \mathrm{l})$ and slightly toxic (10>100 mg/l) (Choudhury, 2018). Accordingly, copper sulfate is considered slightly toxic, while jasper herbicide is moderately toxic. In the present study, the $96 \mathrm{~h}-\mathrm{LC}_{50}$ of copper sulfate $\left(\mathrm{CuSO}_{4} .5 \mathrm{H}_{2} \mathrm{O}\right)$ and jasper herbicide decreased when applied in a mixture. This means that when toxicity increases, the hazardous effects on fish will be increased. Kelly et al. (2016) stated that, fish and their environment are exposed to a wide variety of substances, and there is an increasing concern about the potential adverse effects of the interactions between those substances when present simultaneously in a mixture. This is due to the fact that some chemicals have a synergistic effect and would act jointly in a way that the overall level of toxicity increases more than the effects of each component in the mixture if applied singly. Kanu (2019) found that, the mixture of copper hydroxide and glyphosate herbicide was slightly more toxic to $C$. gariepinus fingerlings than each pesticide acting alone. The $96 \mathrm{~h} \mathrm{LC}_{50}$ value of the pesticide mixture was lower than those of the pesticide alone. It is likely that there was synergistic interaction between glyphosate and copper hydroxide, which may have influenced the toxicity of relatively non-toxic copper hydroxide fungicide. Kortenkamp et al. (2009) recorded that, the risk of individual chemicals is less than the risk of a mixture of chemicals, thus understanding the effects of a pesticide mixture is critical to the ecological risk assessment of pesticides.

Like any organism, fish have a defense mechanism by which they can prevent oxidative stress. These defense mechanisms include antioxidant enzymes like; superoxide dismutase (SOD), catalase (CAT) and glutathione peroxidase (GPX). SOD transforms superoxide anions into hydrogen peroxide, CAT decomposes hydrogen peroxide to molecular oxygen and water, while GPX reduces both hydrogen peroxide and lipid hydro-peroxides (Kopecka-Pilarczyk \& Correia, 2009). The level of antioxidant enzymes have been extensively used as an early warning indicator of pollution (Lin et al., 2001).

In this study, levels of these antioxidants in plasma decreased due to the toxicity of copper sulfate and jasper separately and in mixtures. These findings agree with those of 
Nahas et al. (2016) and Abd-Allah et al. (2019). The decrease in these three antioxidants in plasma may be attributed to the inhibition in their syntheses. Min and Ju-Chan (2008) observed similar results and suggested that the $\mathrm{O}_{2}$ radicals or their transformation to $\mathrm{H}_{2} \mathrm{O}_{2}$ may cause oxidation of cysteine in the enzyme which results in a decrease of SOD activity. Moreover, excess production of ROS may inhibit the SOD activity (Manduzio et al., 2004; Min \& Ju-Chan, 2008). The inhibition of catalase activity may be due to the binding of toxicants-SH groups of enzymes, increased $\mathrm{H}_{2} \mathrm{O}_{2}$ and/or superoxide radical (Ruas et al., 2008). In addition, they may move towards the injured tissues to protect them against oxidation stress as previously found by Hemalatha et al. (2016), Abhijit and Poopal (2016), Naz (2017) and Desai and Bhilave (2018) who recorded an increase of SOD, CAT and GPX in different tissue organs of fish exposed to pesticides or inorganic compounds. In the present study, the mixture of the two pollutants together has the highest significant effect on fish than the single; this means that copper sulfate and jasper herbicide have a synergistic effect when made jointly.

Malondialdehyde (MDA) measurement is used as the index of lipid peroxidation (LPO) and provides a relative measure of the potential pollutants to cause oxidative injury (Vlahogianni et al., 2007). The present investigation showed a general significant decrease in plasma MDA levels in all treated groups on the $4^{\text {th }}$ and $28^{\text {th }}$ day of exposure. Pollutants stress cause oxidative injury due to lipid peroxidation and enzyme inactivation as previously mentioned by (Valko et al., 2004). Also, the decrease in MDA may be due to disturbances in the physiological state of fish and changes in energy demands due to the environmental stress.

Measurement of transaminase (ALT) and alkaline phosphatase (ALP) activities in blood plasma of fish can be used as a diagnostic tool in fish toxicology to identify their general health status and target organs affected by toxicants as an indicator for pesticide toxicity (Agrahari, 2007). The toxicity of the copper sulfate and jasper herbicide increased the hepatic enzymes (ALT \& ALP) activities after the $4^{\text {th }}$ day of exposure, and decreased significantly after the $28^{\text {th }}$ day. The results of ALT and ALP indicate degenerative changes and hypo-function of the liver as the toxicants effects on the hepatocytes in which cellular enzymes are released into the blood through the $4^{\text {th }}$ day of exposure. After that, the synthesis of these enzymes was inhibited due to liver damage leading to a decrease in enzyme levels in the plasma. Farkas et al. (2004) attributed the disturbances in the ALT and ALP enzymes to a variety of conditions, including hepatopancreatic injury that reflect potential damage to parenchymal cells, muscle, intestinal and hepatic injury.

Notably, AChE is responsible for the rapid hydrolytic degradation of the neurotransmitter acetylcholine into the inactive products of choline and acetic acid. The role of $\mathrm{AChE}$ in cholinergic transmission is to regulate the nervous transmission by reducing the concentration of acetylcholine in the junctions. If $\mathrm{AChE}$ is inactivated by any toxicant, acetylcholine concentration will elevate in the junctions leading to continuous stimulation of the muscle or nerve fiber resulting in tetany, paralysis or even death (Bocquene $\&$ 
Galgani, 1998). Insecticides are strong inhibitors of acetyl-cholinesterase. Furthermore, inorganic chemicals like copper compounds show an inhibitory effect on the AChE activity of common prawn, sole, and the dragonet (Olson \& Christensen, 1980). Murat et al., (2006) and Eman et al. (2018) found that AChE activity was lowered due to the effect of heavy metals and pesticides. The same trend was found in the present study, AChE was inhibited due to the effect of sublethal concentrations of copper sulfate and jasper separately and in a mixture through different periods of exposure.

The increase in renal parameters (uric acid \& creatinine) may result from oxidative damage (Prusty $\boldsymbol{e t}$ al., 2011). These results agree with those of Sharafeldin $\boldsymbol{e t}$ al. (2015), who attributed the elevation of uric acid and creatinine to the disturbances in the kidney and the necrosis of endothelial cells and renal homeopathic tissue. The reduction of total plasma albumin could be attributed to the impairment of its synthesis in the damaged liver and/or escaping from the impaired kidney. Similar results were recorded after exposing $C$. gariepinus to the deltamethrin (Amin \& Hashem, 2012).

After transferring the fish to the water completely free of copper sulfate and jasper, fish try to regain their normal physiological state by returning the antioxidants, SOD and MDA back to the normal.Unfortunately, this failed in fish previously exposed to the mixture. The CAT and GPX increased compared to the control in all groups; this may be done to correct the healthy status of the fish. The ALT, ALP AChE, uric acid, creatinine and albumin levels were in a fish attempt to return normal. In contrast, the effect of the mixture of copper sulfate and jasper herbicide was still noticed and may still be impacted for a long time resulting in severe problems.

\section{CONCLUSION}

According to the evaluated $96 \mathrm{~h}-\mathrm{LC}_{50}$, it can be concluded that the toxicity of copper sulfate and jasper herbicide in their mixture is higher than in separate. The activities and expression levels of antioxidant enzymes and oxidative stress can be used as biomarkers to evaluate the influence of copper sulfate, jasper herbicide and their mixture on the biochemical pathway and enzymatic function in the Nile tilapia. Thus, this can be used for biological monitoring of environmental contamination. Fish can regain their health status and overcome the stress if transferred to clean water in a proper time, except those exposed to a mixture of contaminants.

\section{REFERENCES}

Abd-Allah, M. M; Ashraf, A. R; Noha, M. S.; Ibrahim, H. I. and Esam, A. A.

(2019). Effects of cadmium chloride and glyphosate on antioxidants as biochemical biomarkers in Nile tilapia. J. Aquac. Res. Development,10(1):1-6.

Abd El-Aziz, E. A.; Koshaik, M. Y.; Abd El-Fadil, H. A.; Diab, A. S.; Moselhy, S. 
E. and Moustafa, E. S. (1997). Biochemical, residual and histopathological studies in catfish (C. lazera) exposed to some molluscicides. Veterinary Medicine Journal Giza, 45(1): 61-73.

Abhijit, B. D; Ramesh, M. and Poopal, R. K. (2016). Responses of Metabolic and Antioxidant Enzymatic Activities in Gill, Liver and Plasma of Catla catla during Methyl Parathion Exposure. The Journal of Basic and Applied Zoology, 77: 31-40.

Agrahari, S.; Pandey K. C.; Gopal K. (2007). Biochemical Alterations Induced by Monocrotophos in the Blood Plasma of Fish Channa punctatus (Bloch). Pesticide Biochemistry and Physiology, 88: 268-272.

Ahmad, I.; Pacheco, M. and Santos, M. A. (2004). Enzymatic and non-enzymatic antioxidants as an adaptation to phagocyte-induced damage in Anguilla Anguilla L. following in situ harbor water exposure. Ecotoxicol. Environ. Safety, 57(3): 290302.

Allen-Gil, S. M. and Martynov, V.G. (1995). Heavy metal burdens in nine species of Freshwater and anadromous fish from the Pechora River, northern Russia. Sci. Total. Environ. 160/161: 653-659.

Amin, K. A. and Hashem, K. h. S. (2012). Deltamethrin-Induced Oxidative Stress and Biochemical Changes in Tissues and Blood of Catfish (Clarias gariepinus): Antioxidant Defense and Role of Alpha-Tocopherol. BMC Veterinary Research, 8(45): 1-8. http://dx.doi.org/10.1186/1746-6148-8-45

Anam, K. K. and Maitra, S. K. (1995). Impact of Quinaiphos on Blood Glucose and Acetylcholinesterase (AChE) Activity in Brain and Pancreas in a Roseringed Parakeet (Psittaculakrameri borealis: Newmann). Environ. Contam.Toxicol. 1995; 29: 20-23.

Barham, D. and Trinder, P. (1972). Enzymatic determination of uric acid. Analysed, 97:142-145.

Behreus, A. S. and Karbeur, L. (1953). Determination of $\mathrm{LC}_{50}$. Arch. Exp. Path. Pharm, 28: 177-183.

Bergmeyer, H. U. (1974). Methods of Enzymatic Analysis. Academic Press, New York and London, 4:727-771.

Beutler, E. (1975). Red Cell Metabolism: A Manual of Biochemical Methods. $2^{\text {nd }}$ ed. Grune and Straton, New York.

Bocquene, G. and Galgani, F. (1998). Biological effects of contaminants:

Cholinesterase inhibition by organophosphate and carbamate compounds. ICES Techniques in Mariue Environmental Sciences, 22: 1-19.

Borkovic, S. S.; Saponjic, S. J.; Pavlovic, Z. S.; Blagojevic, P. D.; Milosevic, M.

S.; Kovacevic, B. T.; et. al. (2005). The activity of antioxidant defence enzymes in the mussel Mytilus galloprovincialis from the Adriatic Sea.Comp. Biochem. Physiol. C: Toxicol.Pharmacol. 141: 366-374.

Boyd, C. E. (1984). Water Quality in Warm Water Fishponds. Auburn University 
Agriculture Experimental Station, Auburn, Alabama, USA.

Boyd, C. E. (1990).Water Quality in Ponds for Aquaculture. Birmingham Publishing Co, Birmingham, Alabama, USA.

Choudhury, N. (2018). Ecotoxicology of Aquatic System: A Review on Fungicide Induced Toxicity in Fishes. Pro Aqua Farm Marine Biol. 1(1): 180001.

Desai, T. H. and Bhilave, M. P. (2018). Toxicological studies of methanol on superoxide dismutase (SOD) activity of freshwater fish Cirrhinus mrigala. International Journal of Fisheries and Aquatic Studies, 6(5): 20-22.

Doumas, B.T.; Watson, W. A.and Biggs, H. G. (1971). Albumin standards and the measurement of serum albumin with bromcresol green. Clin. Chim. Acta. 31(1): 8796.

EPA (Environmental Protection Authority) (2012). To seek the modification of controls on a number of substances containing haloxyfop-R-methyl, as the active ingredient, to allow their use overwater to control aquatic pest plants. Submission from South Island Eel Industry Association Inc, and North Island eel, pp 9/112.

Ellman, G.; Courtney, D.; Andres, V. and Featherstone, R. M. (1961). A new and rapid colorimetric determination of acetyl-cholinesterase activity. Biochemical Pharmacology. 7(2): 88-90, IN1, 91-95.

El-Sayed, A. F. M. (2013). On-farm feed management practices for Nile tilapia (Oreochromis niloticus) in Egypt. In M.R. Hasan \& M.B. New, eds. On-farm feeding and feed management in aquaculture, pp. 101-129. FAO Fisheries and Aquaculture Technical Paper. 583. Rome, FAO. 585 pp.

Eman, G. E.; Abd El-Atti, M. S. and Yasmina, M. E. (2018). Harmful effects of water pollution on some physiological responses of the Nile tilapia (Oreochromis niloticus) in both Qarun and Burullus Lakes. The Egyptian Journal of Hospital Medicine, 72(2): 4021-4025

Esterbauer, H.; Schaur, R. J. and Zollner , R. H. (1991). Chemistry and biochemistry of 4-Hydroxylnonenal, malonaldehyde and related aldehydes. Free Rad. Biol. Med. 11(1): 81-128.

Farkas , J.; Farkas, P. and Hyde, D. (2004). Liver and gastroenterology tests. In: Lee, M., $3^{\text {rd }}$ ed, Basic Skills in Interpreting Laboratory Data. American Society of Health-System Pharmacists, Bethesda, Maryland, USA, 330-336.

Flohé, L. and Gunzler, W. A. (1984). Assays of glutathione peroxidase. Methods in Enzymology, 105: 114-121.

Flohé, L. and Otting, F. (1984). Assays of superoxide dismutase. Methods in Enzymology, 105: 93-104.

Frenzilli, G.; Scarcelli, V.; Del Barga, I.; Nigro, M.; Frlin, L.; Bolognesi, C. and Sturve, J. (2004). DNA damage in eelpout (Zoarces viviparus) from Göteborgharbour.Mutat. Res. 552: 187-195.

Hemalatha, D.; Amala, A.; Rangasamy, B.; Nataraj, B. and Ramesh, M. (2015). 
Sublethal Toxicity of Quinalphos on Oxidative Stress and Antioxidant Responses in a Freshwater Fish (Cyprinus carpio). Environmental Toxicology. 2016; 31(11):1399-1406. doi:10.1002/tox.22145. Epub, Apr 21.

Henry, R. J. (1964). Colorimetric determination of total protein. In: Clinical Chemistry. Harper and Row PubL. New York. pp 181.

Kanu, C. K. (2019). Acute toxicity of copper hydroxide and glyphosate mixture in Clarias gariepinus: interaction and prediction using mixture assessment models. Environmental Health and Toxicology. 34(1):1-8.

Kelly, A. H.; Richard, F.; Shore, M.; Glória, P.; Kevin, C. J. and Francis, L. M. (2016). Risk assessment of environmental mixture effects. RSC Adv. 6: 4784447857.

Khoshnood, Z . (2017). Effects of environmental pollution on fish: a short review: Transylv. Rev. Syst. Ecol. Res. "The Wetlands Diversity". 19(1): 49-60.

Kopecka-Pilarczyk, J. and Correia, A. D. (2009). Biochemical response in gilthead seabream (Sparus aurata) to in vivo exposure to a mix of selected PAHs. Ecotoxicol. Environ. Saf. 72: 1296-1302.

Kortenkamp, A.; Backhaus T. and Faust, M. (2009). State of the art report on mixture toxicology. In: Report Commissioned by the European Commission, DG Environment, pp 22-25

Lin, C. T.; Lee, T. L.; Duan, K. J. and Su, J. C. (2001). Purification and Characterization of Black Porgy Muscle Cu/Zn Superoxide Dismutase. Zoological Studies. 40(2): 84-90.

Lopez-Lopez, E.; Sedeno-Diaz, J. E.; Soto, C. and Favari, L. (2011). Responses of antioxidant enzymes, lipid peroxidation, and Na?/K?-ATPase in liver of the fish Goodea atripinnis exposed to Lake Yuriria water. Fish Physiol. Biochem. 37: 511522.

Manduzio, H.; Tiphaine, M.; Camille, G.; François, L. and Béatrice R. (2004).

Seasonal variations in antioxidant defences in blue mussels Mytilus edulis collected from a polluted area: major contributions in gills of an inducible isoform of $\mathrm{Cu} / \mathrm{Zn}$ superoxide dismutase and of glutathione $S$-transferase. Aquatic Toxicology, 70(1): 83-93.

Mastin, B. J. and Rodgers, J.H. (2000). Toxicity and bioavailability of copper herbicides (clearigate, cutrine-plus, and copper sulfate) to freshwater animals. Archives of Environmental Contamination and Toxicology, 39: 445-451.

Min EY, Ju-Chan K. (2008). Effect of waterborne benomyl on the hematological and antioxidant parameters of the Nile tilapia, Oreochromis niloticus. Pestic. Biochem. Physiol, 92(3):138-143.

Murat, O.; Abbas, G.; Zehra, K. and Elif, G. (2006). Monitoring the effects of water pollution on Cyprinus carpio in Karakaya Dam Lake, Turkey. Ecotoxicology, 15(2): 157-169. 
Nahas, A. A.; Aly, F. A. and Reem, M. Z. (2016). Biochemical responses of freshwater fish Oreochromis niloticus to glyphosate-based herbicides in relation to physico-chemical properties. Egy. Sci. J. Pestic, 2: 96-101.

Naz, H. (2017). Pesticides Mixture Toxicity; Effects on Superoxide Dismutase Activity in Indian Major Carps. Pakistan Journal of Agricultural Sciences, 54(3): 607-611.

Prusty, A. K.; Kohli, M. P. S.; Sahu, N. P.; Pal, A. K.; Saharan, N.; Mohapatra, S. and Gupta, S. K. (2011). Effect of Short Term Exposure of Fenvalerate on Biochemical and Hematological Responses in Labeo rohita (Hamilton) Fingerlings. Pesticide Biochemistry and Physiology 100: 124-129.

Ohkawa, H.; Ohishi, N. and Yagi, K. (1979). Assay for lipid peroxides in animal tissues by thiobarbituric acid reaction. Anal. Biochem, 95(2): 351-358.

Olson, D. L. and Christensen, G. M. (1980). Effects of water pollutants and other chemicals on fish acetylcholinesterase in vitro. Environmental Research. 1980; 21: 327-335.

Reitman, S. and Frankel, A. S. (1957). A colorimetric method for the determination of serum glutamic oxaloacetic and glutamic pyruvic transaminases. Am J Clin Pathol. 28: 53-56.

Ruas, C. B.; Carvalho, C. S.; de Araujo, H. S.; Espindola, E. L. and Fernandes, M. N. (2008). Oxidative stress biomarkers of exposure in the blood of cichlid species from a metal-contaminated river. Ecotoxicol. Environ. Saf. 71: 86-93.

Sharafeldin, K. h.; Abdel-Gawad, H.; Ramzy, E.; Sweilum, M. and Nagy, M. (2015). Harmful impact of profenofos on the physiological parameters in Nile tilapia, O. niloticus. International Journal of Basic and Applied Sciences, 4(1): 1926.

Stajner, D.; Popovic, M. and Stajner, M. (2003). Herbicide Induced Oxidative Stress In Lettuce, Beans, Pea Seeds and Leaves. Biologia Plantarum. 47(4): 575579.

Valko, M.; Izakovic, M.; Mazur, M.; Rhodes, C. J. and Telser, J. (2004). Role of Oxygen radicals in DNA damage and cancer incidence. Mol. Cell Biochem. 226: $37-56$.

Vlahogianni, T.; Dassenakis, M.; Scoullos, M. J. and Valavanidis, A. (2007). Integrated Use of biomarkers (superoxide dismutase, catalase and lipid peroxidation) in mussels Mytilus galloprovincialis for assessing heavy metals' pollution in coastal areas from the Saronikos Gulf of Greece. Mar. Pollut. Bull. 54: 1361-1371.

Wagner, J. L.; Andrea, K.T.; Amanda, E. V. and Eric, A.P. (2017). Temperature and toxicity of the copper herbicide (NautiqueTM) to freshwater fish in field and laboratory trials. Cogent Environmental Science, 3: 1-13.

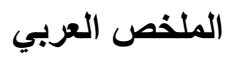




\section{تأثير مزيج من الملوثات البيئية على بعض المؤشرات الحيوية في أسماك البلطي النيلي \\ Oreochromis niloticus}

إيمان عطية عبد السميع عبد الحميد 1 ، شيرين حسين هاشم 2 ، أماني عبد العزيز غريب 3

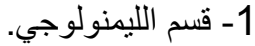

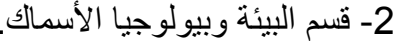

3- قسم التفريخ وفيسيولو جيا الاسماك.

مركز البحوث الزر اعبة ، المعل المركزي لبحوث الثروة السمكية ، العباسة ، أبو حماد ، الثرقية ، مصر.

تستخدم كبريتات النحاس ومبيد الحشائش (جاسبر) بكثافة في البيئة المائية لقتل الطحالب و البكتيريا و الرخويات و النباتات غير المرغوب فيها. لذلك أجريت هذه الدراسة لتقييم تأثير السمية المزمنة لتلك التئ المركبات بشكل منفصل ومختلط على بعض المؤشرات الحيوية في البلطي النيلي

.niloticus

وقد وجد أن التركيز المميت النصفى من كبريتات النحاس منفردا هو 33.50 مجم / لتر و الذي انخفض في الخليط إلى 11.70 مجم / لتر ، بينما في حالة الجاسبرمنفردا كان 3.80 مجم / لتر و الذي انخفض إلى الى

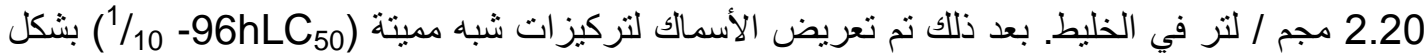

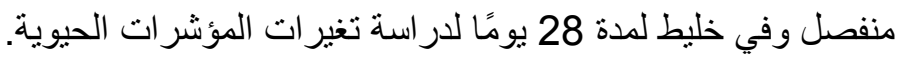

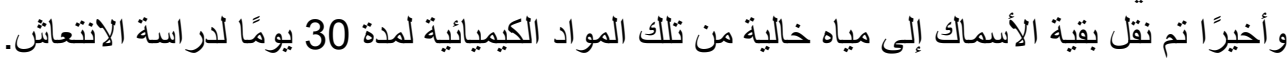

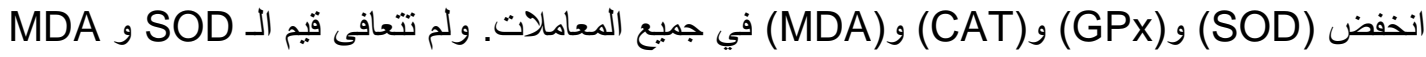
في الأسماك المعرضة للخليط. وتجاوزت قيم الـ GPX و CAT أثناء الانتعاش مثنيلاتها في المجموعة

الضابطة (الكنترول) وكان تأثير الخليط هو الأعلى. ارتفعت مستويات كل من انزيم Alanine) في جميع العلاجات في اليوم الرابع (alkaline phosphatase; ALP) و Transaminase; ALT) و انخفض في اليوم الثامن والعشرين من التعرض ولم يتعافى. انخفض أسيتيل كولينستريز (AChE) في

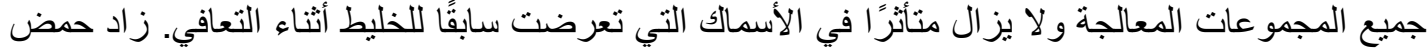

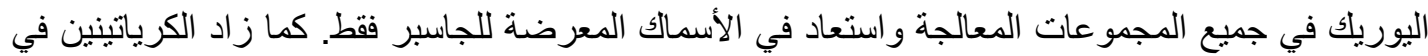

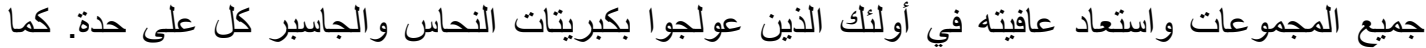

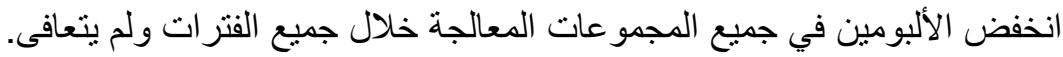
وبناء علي ماسبق فإن سمية خليط كبرينات النحاس ومبيد الأعشاب "جاسبر" باللنسبة لسمكة البلطي النيلي

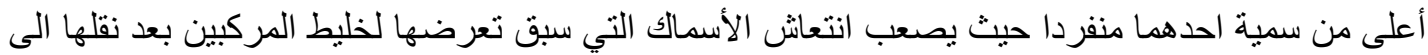

